\title{
Hezychazm i kultura
}

\author{
Сергей Хоружий
}

Instytut Filozofii Rosyjskiej Akademii Nauk w Moskwie (Rosja)

Сергей Хоружий, Hesychasm and culture, transl. ks. Łukasz Leonkiewicz, Elpis, 16 2014: 143-149.

\begin{abstract}
The purpose of this paper is to provide a systematic comparison of two phenomena: hesychasm and culture. For this purpose, a common language should be developed. Initially, we describe the development of contemporary research on hesychasm, in order to then indicate the interaction between the two phenomena. The convergence of the relations of hesychasm and culture, spiritual traditions and cultural traditions, takes the form of co-operation and dialogue.
\end{abstract}

Streszczenie: Zadaniem niniejszego tekstu jest systematyczne porównanie dwóch fenomenów: hezychazmu i kultury. W tym celu należy wypracować dla ich opisu jeden język. Początkowo opiszemy rozwój współczesnych badań nad hezychazmem, by następnie wskazać wzajemne relacje dwóch fenomenów. Konwergencja relacji hezychazmu i kultury, tradycji duchowej i tradycji kulturowej, przybiera formę współpracy i dialogu.

Keywords: hesychasm, culture

Słowa kluczowe: hezychazm, kultura

We współczesnym, szybko zmieniającym się świecie temat naszego spotkania ${ }^{1}$ - Hezychazm i kultura - również zmieniał się gwałtownie w sposobie ujęcia i rozumienia obu kwestii. Przez długi czas zmiany były jednak niewielkie; relacja praktyki hezychastycznej wobec sfery kultury przez długi czas była postrzegana według wzorca, który odpowiadał ogólnym stereotypom świadomości zsekularyzowanej. W kręgu tych stereotypów jedną z głównych i zasadniczych zawsze była opozycja religii i kultury, przy czym z religii wydzielane były w sposób szczególny monastycyzm i asceza jako przejawy skrajnej, fanatycznej religijności, jako najbardziej wrogie kulturze, progresowi i wolności rozumu. Natomiast hezychazm jako starożytna praktyka ascetyczna i monastyczna, wymagająca odejścia od życia społecznego i kultywująca niezrozumiałe strategie zachowań, dziwne psychotechniki, uznawany był za zjawisko całkowicie marginalne i nieraz zaliczany był do szeregu anomalii psychicznych i patologii. Tego rodzaju stosunek do hezychazmu utrwalił się. Dominował nawet w środowisku religijnym, a nawet $\mathrm{w}$ świecie prawosławnym. A gdyby przetrwał do naszych dni, to temat Hezychazm i kultura byłby całkowicie bezprzedmiotowy. Moglibyśmy wówczas jedynie stwierdzić, że hezychazm i kultura nie mają ze sobą niczego wspólnego, a ich wzajemne relacje sprowadzają się do wzajemnego antagonizmu.

Jednakże dzisiaj tego typu recepcja hezychazmu przeszła już do historii. Różne warunki i czynniki wpłynęły na tę kardynalną przemianę. Oczywiście, nowa recepcja związana była w sposób bezpośredni z dokładnym, głębokim zbadaniem hezychazmu, co powoli stało się wielką transdyscyplinarną sferą badań humanistycznych, która poruszała problematykę historii i patrologii, teologii, filozofii, psychologii, filologii. Jednakże już sama analiza tych badań jako konieczna przesłanka posiadała ważne wspólne poru-

\footnotetext{
Niniejszy tekst wygłoszony został w Stołecznym Centrum Edukacji Kulturalnej w Warszawie 20.05.2014 r.
}

szenia w sytuacji duchowej i kulturowej. Temat Hezychazm $i$ kultura jako część organiczna wchodzi w skład szerokiej tematyki Religia i kultura, a stosunek do hezychazmu w społeczeństwie i kulturze formują procesy dokonywujące się w tym szerokim kontekście. Z kolei, relacje między sferami religii i kultury współcześnie zależały od globalnego procesu sekularyzacji, który przez długi czas stanowił istotę i specyfikę rozwoju kulturowego Zachodu. Począwszy od Renesansu i Oświecenia, w rozwoju tym dominowała tendencja wydzielania autonomicznej pozareligijnej sfery w świadomości i życiu społecznym, a następnie stopniowego powiększania i wzmacniania tej sfery. Emancypacja świadomości niereligijnej (świeckiej, zsekularyzowanej) powoli przemieniała się w ekspansję, w konfrontację ze świadomością religijną, by ostateczne wypchnąć na peryferia tę ostatnią, poza granice życia publicznego, poza przestrzeń kultury i nauki. Proces sekularyzacji postępował, a w wieku XX osiągnął stadium graniczne, bliskie pełnego usunięcia religii i świadomości religijnej z życia publicznego. Sekularyzm został na Zachodzie uznany za ideologię panującą, chociaż w różnych kulturach Zachodu w dość różnych formach i w różnym stopniu.

Jednocześnie, równolegle do wzmocnienia sekularyzmu, w najróżniejszych sferach zaczęły przejawiać się jego skutki, negatywne strony i konsekwencje. Doktryna sekularyzmu posługiwała się zbyt ogólnym i spornym wyobrażeniem religii, świadomości religijnej i ich roli w społeczeństwie oraz dla człowieka. U swych podstaw była ona blisko związana z metafizyką klasyczną i klasyczną koncepcją człowieka Arystotelesa-Kartezjusza-Kanta, a kryzys metafizyki klasycznej, który dokonał się w wieku XX, spowodował również kryzys owej doktryny. Walczący, radykalny sekularyzm wyczerpał się; i mimo iż wyraźne przyznanie się do tego, przedłożenie koncepcji alternatywnych zaczęło się pojawiać dopiero pod koniec $\mathrm{XX}$ wieku, to w różnych sferach kultury i życia publicznego także wcześniej pojawiały się fenomeny i trendy innej natury, którą dziś nazy- 
wamy postsekularyzmem. Jednym z głównych i wyraźnych przykładów tego jest kultura Srebrnego Wieku w Rosji. Jest to kultura o charakterze synkretycznym, aleksandryjskim, która przyjmowała całe mnóstwo najróżniejszych nurtów i kierunków, tak religijnych, jak i świeckich, które powiązane były miedzy sobą, $\mathrm{w}$ dużej mierze, nie relacjami konfrontacji, lecz owocnego współoddziaływania i dialogu. Jednym z głównych jej zjawisk jest, tak zwany rosyjski renesans religijno-filozoficzny: burzliwy rozwój filozofii rosyjskiej pod koniec XIX i na początku XX wieku zainspirowany twórczością F. Dostojewskiego i Włodzimierza Sołowjowa, w którym zrodziła się współczesna potrzeba zapoznania się z tradycją prawosławną, co wzbogaciło tak Prawosławie, jak i filozofię. $\mathrm{Z}$ tego powodu należy wspomnieć pewien epizod, słynne zebrania religijno-filozoficzne w latach 1901-1903, jakie miały miejsce w Sankt-Petersburgu. Była to cała seria spotkań przedstawicieli Cerkwi Rosyjskiej z myślicielami świeckimi, podczas których dyskutowano o drażniących i spornych kwestiach dotyczących duchowo-kulturowej kondycji państwa. Natomiast sam ich zamysł można określić jako spotkanie religii i kultury. W wyniku tego, wraz z rozwojem kryzysu sekularyzacji, opozycja religii i kultury powoli traciła ostrość, dokonywała się jej ponowna analiza i na nowo przemyślano jej podstawy. W życiu politycznym i kulturowym wzmacniały się zjawiska, które Peter Berger zakwalifikował do grupy zjawisk desekularyzacji i które następnie były interpretowane jako początek wstępowania $\mathrm{w}$ paradygmat postsekularyzacji. W tym nowym paradygmacie, który zastąpił paradygmat sekularyzacji, relacje świadomości religijnej i świeckiej, a także relacje religii i kultury, przechodzą od konfrontacji do dialogu. Analogiczną ewolucję przeszły także relacje hezychazmu i kultury.

\section{1.}

Pokrótce opiszemy rozwój współczesnych badań nad hezychazmem. Zainteresowanie tradycją ascetyczną prawosławia pojawiło się już w okresie rosyjskiego renesansu religijno-filozoficznego, kiedy podkreślono jej znaczenie dla charakteru świadomości rosyjskiej oraz dla ludowej religijności. Jednakże myśliciele tego okresu nie zajmowali się badaniami nad hezychazmem, nawet $\mathrm{w}$ najmniejszy sposób nie przyczynili się do lepszego zrozumienia tej tradycji; ich zainteresowanie ascezą prawosławną wyrażone zostało jedynie poprzez aktywne zaangażowanie się $\mathrm{w}$ imiesławie - niewielki ruch w środowisku monastycznym na początku XX wieku, który był jedynie marginalnym odchyleniem od wypracowanej przez stulecia nauki hezychastycznej. Nie dokonała się wówczas całkowita recepcja hezychazmu jako zjawiska historycznego i duchowego, niemniej jednak fenomen hezychazmu w pewnej mierze został wciągnięty w pole zainteresowań myśli rosyjskiej. Nowa, współczesna jego recepcja dokonała się w myśli emigracyjnej, a ogromną rolę $\mathrm{w}$ tym procesie odegrał nurt teologiczny myśli rosyjskiej, który zasłynął jako neopalamizm, czyli współczesna wersja nauki jednego z największych teologów he- zychastycznych św. Grzegorza Palamasa (1296-1357). U źródeł tego nurtu legły dzieła młodych teologów emigracji rosyjskiej, a przede wszystkim trzy fundamentalne prace: Hieromnicha Bazylego (Krywoszeina), Ascetyczna $i$ teologiczna nauka św. Grzegorza Palamasa (1936), Włodzimierza Łosskiego, Teologia mistyczna Kościoła Wschodniego (1944), oraz o. Johna Meyendorffa, Wprowadzenie do badań nad św. Grzegorzem Palamasem (1959).

$\mathrm{Na}$ tym etapie nastąpił wyraźny, głęboki powrót do samych korzeni hezychazmu, do dziedzictwa hezychastycznego, które dotychczas pozostawało nie tylko słabo zbadane, lecz w większej części także nieopublikowane (wystarczy wspomnieć, iż główny, kluczowy tekst myśli hezychastycznej, Triady w obronie świętych hezychastów Grzegorza Palamasa, po raz pierwszy opublikowany został dopiero w 1959 r. przez J. Meyendorffa). Jak powszechnie wiadomo, neopalamizm przyciągnął do siebie wielu zwolenników ze wszystkich państw prawosławnych i był przyczyną nowego poruszenia myśli prawosławnej, stając się na długo jej głównym nurtem (wraz z przyległym do niego nurtem syntezy neopatrystycznej głoszonej także przez emigranta rosyjskiego, Jerzego Florowskiego).

Neopalamizm dużo uwagi poświęcił hezychazmowi i to dzięki jego licznym kapitalnym opracowaniom tradycja hezychastyczna na trwałe uznana została za rdzeń i trzon duchowości prawosławnej. Jednakże, mimo iż neopalamizm wniknął głęboko w teologię palamasową i hezychastyczną, nie stworzył jeszcze całościowej współczesnej recepcji hezyhazmu, czego zresztą stworzyć nie mógł, ponieważ hezychazm nie jest bynajmniej fenomenem czystko teologicznym. Pozostawał jeszcze jeden istotny krok do zrobienia: konieczne było takie spojrzenie na hezychazm, w którym dostrzeże się go jako jedno zjawisko w całej pełni jego aspektów i wymiarów. Hezychazm jest praktyką mistyczno-ascetyczną, która realizowana jest przez całokształt ludzkiego istnienia, przez człowieka integralnego, w którym aktywne są wszystkie poziomy jego organizacji - intelektualny, psychiczny i fizyczny. Dlatego droga do dostrzeżenia go w całości mogła zostać odkryta jedynie przez wszechstronną rekonstrukcję tej integralnej antropopraktyki, czyli przez antropologię hezychastyczną, opierającą się na analizie doświadczenia hezychastycznego. Jej skonstruowanie zostało podjęte w moich pracach. Na potrzeby naszej problematyki wystarczy jedynie wskazać jej główne zasady i konstrukcje.

Przede wszystkim, pojawia się tu charakterystyczne, nowe podejście do hezychazmu, który postrzegany jest jako zjawisko duchowo-antropologiczne. Praktyka hezychastyczna interpretowana jest jako pewien specyficzny rodzaj „technik siebie”, w nawiązaniu do znanego pojęcia wprowadzonego przez M. Foucaulta. Zgodnie z Foucault, technika siebie jest praktyką autoreorganizacji człowieka, która porusza wszystkie poziomy organizacji istnienia ludzkiego i stopniowo dąży do konkretnego, wcześniej już obranego celu - swego rodzaju poszukiwanego finalnego stanu świadomości i człowieka integralnego. Praktyce hezychastycznej odpowiada dość specyficzny wybór stanu finalnego ( $w$ dodatku takiego, którego sam Foucault nie 
uznawał za możliwy): praktyka ta dąży do zmiany najbardziej fundamentalnych predykatów ludzkiego istnienia, które określają sposób bycia człowieka. To aktualne transcendowanie istnienia ludzkiego dyskurs doświadczenia hezychastycznego nazywa spotkaniem energii człowieka z energiami innego, boskiego bycia, takie spotkanie, w którym osiągana jest zgodna współpraca tych różnych pod względem ontologicznym energii (synergia) i wstępowanie ku doskonałemu zjednoczeniu całej pełni ludzkich energii $\mathrm{z}$ energiami boskimi (przebóstwienie, theosis, doskonała pełnia, która pozostaje jednak nieosiągalna w granicach tutejszej rzeczywistości). Pod względem antropologicznym, najważniejszą różnicą tej holistycznej praktyki jest jej konstytutywny charakter: $\mathrm{w}$ doświadczeniu wstępowania ku synergii, a następnie ku przebóstwieniu, czyli w doświadczeniu spotkania z kimś Innym pod względem ontologicznym, formułowana jest konstytucja człowieka, podstawowe struktury jego osobowości i identyczności; innymi słowy konstytuowana jest konkretna formacja antropologiczna. $\mathrm{Na}$ pierwszy rzut oka stwierdzeniu o fundamentalnej pod względem antropologicznym roli praktyki hezychastycznej przeczy jej marginalna pozycja w społeczeństwie, to, że ogranicza się do małego, wąskiego grona. Należy jednak zwrócić uwagę na jeden zasadniczy szczegół tej praktyki (jak i praktyk duchowych innych religii): wydobywane przez nią doświadczenie w oczach świadomości społecznej jest szczególne, unikalne, wartościowe, dzięki czemu jej wpływ może stać się rozległy i silny. Pojawia się cały krąg najróżniejszych „praktyk przyległych”, które zorientowane są na praktykę hezychastyczną, zapożyczają jej elementy. To właśnie dzięki tym praktykom przyległym konstytucja człowieka, formułowana w swym całokształcie w łonie hezychazmu, przyswajana jest, choć nie w tymże całokształcie, przez społeczeństwo i staje się dominującą $\mathrm{w}$ nim formacją antropologiczną.

Ze wskazaną różnicą antropologiczną bezpośrednio związana jest kluczowa różnica religijna: $\mathrm{z}$ punktu widzenia nauki prawosławnej doświadczenie ascezy hezychastycznej jest doświadczeniem dążenia do Chrystusa i zjednoczenia z Nim w Jego energiach, poprzez Ducha Świętego; doświadczenie to $\mathrm{z}$ kolei postrzegane jest jako kwintesencja autentycznego doświadczenia chrześcijańskiego, życia w wierze chrześcijańskiej. Odnalezienie tego doświadczenia staje się celem i przeznaczeniem życia chrześcijańskiego, przy czym nie tylko dla ascetów-hezychastów, lecz dla wszystkich chrześcijan, nawet jeśli doświadczenie to nie jest przez nich odnajdowane $\mathrm{w}$ pełni, a jedynie $\mathrm{w}$ pewnej mierze, różnej dla każdego, zgodnie z zasadą „ile kto pomieści”. Właśnie na mocy tej kwintesencyjności doświadczenia hezychastycznego, która wydziela je spośród różnorodności doświadczenia religijnego, hezychazm pełni główną rolę w świecie duchowości i kościelności prawosławnej.

Już w tej krótkiej charakterystyce zauważamy, że przedstawiony sposób pojmowania hezychazmu rozwija się w paradygmacie postsekularnym, ponieważ łączy analizy hezychazmu w religijno-teologicznej i w sekularno-naukowej perspektywie (rozróżniając je przy tym jednocześnie, a nie mieszając i łącząc). Ów sposób pojmowania w swej pełnej formie przejawia swój postsekularny charakter jeszcze mocniej, gdy stopniowo analizuje ascetyczne prapoczątki, uwzględniając interpretacje teologiczne i opierając się na zasadach epistemologicznych filozofii współczesnej. Jako cechę charakterystyczną można wyróżnić, na przykład to, że badanie struktur doświadczenia hezychastycznego wskazało na głębokie pokrewieństwo i podobieństwo miedzy hezychastycznymi technikami uwagi i czujności a mechanizmami świadomości intencjonalnej w fenomenologii Husserla. W sposób nieunikniony, w ramach tego współczesnego pojmowania hezychazmu pojawia się także nowe ujęcie relacji hezychazmu i kultury.

\section{2.}

W celu systematycznego porównania dwóch fenomenów należy wypracować dla ich opisu jeden język. W antropologii synergicznej podczas analizy procesów rozwoju kulturowo-cywilizacyjnego głównym pojęciem jest tradycja. Rozumiem to pojęcie w sposób najszerszy i najogólniejszy. Tradycję rozumiem jako jedność translacji (czyli przekazu) w przestrzeni społeczno-kulturowej, która posiada dwie cechy: 1) treści wchodzących w nią translacji posiadają wartość dla członków tego społeczeństwa, w którym translacja się dokonuje; 2) mechanizmy owych translacji charakteryzują się pamięcią (tzn. zależnością od poprzedzających translacji, wprowadzającą łączność w całej jej pełni). Organizm kulturowo-cywilizacyjny zawiera w sobie liczne i różnorodne tradycje (kulturowe, religijne, etniczne i inne), a jego rozwój określony jest przez procesy istnienia i wzajemnego oddziaływania tych przeplatających się tradycji. Różne tradycje w różnej mierze są istotne i oddziaływujące na ów rozwój, a w związku z tym kierująca i dominująca rola przynależy raz jednej raz drugiej tradycji.

Jakby dziwnie to nie wyglądało, ta prosta konceptualizacja pozwala już nam w pełni sensownie przeanalizować relacje hezychamu i kultury. Sfera kultury w tym kontekście jest „tradycją kulturalną”, która z kolei stanowi obszerny kompleks-konglomerat różnorodnych sub-tradycji - naukowych, artystycznych, pedagogicznych itd. W nich zawarty jest także hezychazm, z którym także związana jest konkretna tradycja. Hezychazm często opisywany jest przy pomocy dwóch formul: „praktyka hezychastyczna” i „tradycja hezychastyczna". Teraz musimy wyeksponować ich wspólny sens. Praktyka hezychastyczna, jak już mówiliśmy, jest techniką siebie, którą indywidualnie wypełnia asceta; tym samym jest to zjawisko na wskroś antropologiczne. Natomiast tradycja hezychastyczna mówi o społeczności wszystkich adeptów praktyki hezychastycznej i tym samym jest zjawiskiem społecznym bądź dokładniej, socjohistorycznym, ponieważ społeczność ta ochraniana jest i podtrzymywana w pokoleniach, w historii. Jest to jednak specyficzne zjawisko społeczne, które zawiera w sobie istotne aspekty antropologiczne. Każda tradycja charakteryzuje się, przede wszystkim, treścią, która jest przekazywana $\mathrm{w}$ procesie translacji, a w przypadku tradycji hezychastycznej treścią tą jest doświadczenie praktyki hezychastycznej 
- doświadczenie antropologiczne, a ponadto formułujące konstytucje człowieka. Inną podstawową cechą tradycji jest mechanizm przekazywania treści, którym dla tradycji hezychastycznej jest kontakt osobisty, czyli ponownie fenomen antropologiczny.

W związku z tym, tradycja hezychastyczna jest zjawiskiem, które przynależy, w naszej terminologii, interfejsowi tego, co społeczne i tego, co antropologiczne: $\mathrm{w}$ wyniku więzi z praktyką hezychastyczną tradycja bezpośrednio przekazuje oddziaływanie czynników antropologicznych, a, przede wszystkim, czynników konstytucji człowieka na społecznym poziomie rzeczywistości. Następnie należy zauważyć i powagę tego rodzaju oddziaływań: współcześnie wydaje się, że poziom antropologiczny rzeczywistości globalnej odgrywa główną rolę w jej rozwoju, a globalna dynamika określana jest przez dynamikę antropologiczną nie w mniejszym stopniu niż społeczną. Dlatego kanały, instancje, mechanizmy, które reprezentują rzeczywistość antropologiczną na poziomie społecznym stają się nadzwyczaj ważne; w całym zespole wszystkich tradycji, które określają rozwój rzeczywistości globalnej, tradycja duchowa, przekazująca konstytuujące doświadczenie antropologiczne praktyki duchowej, powinna być uznana za tradycję wiodącą. Jednakże tradycją wiodącą nie może nie być także tradycja kulturowa. Organizm kulturowo-cywilizacyjny nazywa się często po prostu „kulturą", a liczne (sub-) tradycje, wchodzące w skład tradycji kulturowej, otaczają wszystkie sfery tego organizmu - państwo, politykę, naukę, sztukę, wykształcenie i inne - tworząc pełnowartościową zasadę jego rozwoju. Dlatego $w$ procesie rozwoju jakiejkolwiek kultury główna rolę odgrywaja tradycja kulturowa $i$ tradycja duchowa $w$ ich wzajemnym oddzialywaniu; a w przypadku kultury wschodniochrześcijańskiej role tradycji duchowej odgrywa hezychazm.

Temat „hezychazm i kultura” posiada zatem zasadnicze znaczenie: widzimy, że zestawiane ze sobą fenomeny prezentują konkretne tradycje, które wspólnie odgrywają główną rolę w procesie rozwoju wschodniochrześcijańskiego organizmu kulturowo-cywilizacyjnego. W toku tego procesu na mocy konieczności spotykają się one ze sobą, oddziałują na siebie, a między nimi dochodzi do swego rodzaju podziału funkcji. Hezychazm, jako tradycja duchowa, warunkuje antropologiczne aspekty tego procesu i, w pierwszej kolejności, odpowiadający mu paradygmat konstytucji człowieka, natomiast tradycja kulturowa warunkuje to, co dokonuje się w wymiarze społecznym. Jednakże bardzo istotne jest to, że podział ten jedynie wskazuje główne sfery obu tradycji, nie ograniczając ich bynajmniej tymi sferami. Tradycja hezychastyczna w pewnych momentach może odgrywać główną rolę, a niekiedy nawet pierwszoplanową w rzeczywistości społecznej, dlatego poniżej pokazując oddziaływanie na siebie tych dwóch tradycji w historii podkreślimy najważniejsze z tych momentów. Praktyki kulturowe, z kolei, częstokroć posiadają istotne aspekty antropologiczne: najwyraźniej można to dostrzec, na przykład, w praktykach pedagogicznych bądź artystycznych, a wiele praktyk społecznych i tradycji wpływa również na rzeczywistość antropologiczną.
W relacji tej należy wskazać i to, że priorytet praktyki i tradycji duchowej - a w naszym przypadku hezychazmu - w formułowaniu się konstytucji człowieka często był podważany na rzecz praktyk społecznych bądź artystycznych. $\mathrm{W}$ pierwszym przypadku rola tradycji duchowej była odrzucana z pozycji socjocentrycznych, które dominowały przez długi czas (przede wszystkim w formie marksizmu, lecz także i w innych formach) i byly powszechnie znane. $\mathrm{W}$ dużo mniejszym stopniu mówiło się o stanowisku, które absolutyzuje rolę sztuki i głosi, iż ma ona przed sobą misję aktualnego tworzenia wyższej rzeczywistości i konstytuowania osoby człowieka. Ponadto jest ono charakterystyczne dla kultury modernizmu europejskiego, w której zostało szeroko opisane. W sposób jawny wyraziło się ono w sztuce rosyjskiego Srebrnego Wieku - w symbolizmie, w nurcie, który nazywano „poszukiwaniami teurgicznymi”, w twórczości Skriabina, W. Iwanowa i innych. Wdzięcznym dla niego gruntem okazał się przede wszystkim teatr, który jest przecież najbardziej syntetyczną sztuką; niewątpliwie, jednym z najczystszych i radykalnych doświadczeń jego realizacji jest teatr Antonina Artauda - bądź dokładniej, fenomen Artauda w całej jego pełni, w jego teatralnych teoriach, eksperymentach i w całym jego tragicznym życiu.

Porównanie do tego stanowiska wcale nie jest dla nas bezpodstawne, bowiem daje ono możliwość dostrzeżenia obustronnej relacji praktyk duchowych i kulturowych jako ich, swego rodzaju, ekonomię, uzgodnioną współpracę w celu antropologicznej „ekonomii”. Z naszego punktu widzenia to właśnie praktyka duchowa, hezychazm, stwarza w świecie wschodniochrześcijańskiem konstytucję człowieka, struktury jego osobowości i identyczności, natomiast wszelkie praktyki kulturowe, estetyczne, artystyczne nie mają charakteru konstytuującego człowieka, nie są konstytutywne. Jednocześnie nie są one bynajmniej obce tym strukturom, wręcz przeciwnie, bowiem w konstytucji człowieka, udzielają się one w sposób aktywny i oddziałują na nie. Istnieje tylko jedno ograniczenie: nie mogą one stworzyć ich zasad, ich początkowego rdzenia - to właśnie jest prerogatywą wyłącznie praktyki duchowej. W konsekwencji miedzy dwoma rodzajami praktyk pojawia się swego rodzaju „podział pracy”. Praktyka duchowa, i tylko ona, wytwarza doświadczenie kwintesencjalne, w którym aktualizuje się konkretny paradygmat konstytucji człowieka i powstają podstawy formacji antropologicznej. Natomiast praktyki kulturowe na różne sposoby rozwijają owe podstawy: dostarczają one scenę, teatr, poligon pod ich doświadczanie i analizę. Ponadto, traktują je w sposób aktywny i twórczy: odsłaniają wszystkie ich strony i możliwości, artykułują identyczność człowieka, przeprowadzają swego rodzaju trening subiektywności, struktur osobowości, które badają i doprowadzają je do pełni i skończoności. W tych praktykach i z ich pomocą konstytucja człowieka może osiągać pełnię i wszechstronną aktualizację, do tego stopnia, że człowiek otrzymuje możliwość dopełnienia, całkowitego spełnienia się - dostrzeżenia i zrozumienia "prawdziwego siebie”.

Wypełniając swoją misję praktyki kulturowe przyjmują antropologiczny fundament, który powstaje w prakty- 
ce duchowej. Pod tym względem są one zorientowane na praktykę duchową i dlatego przynależą do wprowadzonej powyżej kategorii „praktyk przyległych”. Jednakże w kategorii tej zajmują one miejsce szczególne: one nie tylko zależą od praktyki duchowej, lecz kontynuują jej dzieło, wprowadzając w nie własny, cenny wkład. Baza stwarzana przez praktykę duchową rozwijana jest w nich w najróżniejszych kierunkach, poprzez co rozprzestrzeniany jest wpływ i oddziaływanie praktyki duchowej w różnych sferach osobowości człowieka i w różnych sferach jego aktywności. Otwierają się w nich różnorodne, a czasami nawet nieoczekiwane, ślady zasad i uwarunkowań praktyki duchowej, jakie pokazują całe jej kulturowe i społeczne znaczenie. Takie praktyki, które bazują na praktyce duchowej i dodatkowo dopełniają jej treść, nazywamy praktykami podtrzymujacymi. $\mathrm{W}$ ten sposób, praktyka hezychastyczna i praktyki kulturowe oddziatuja na siebie podobnie jak konstytutywna praktyka antropologiczna i jej praktyki podtrzymujace.

Należy także zwrócić uwagę na to, że podobne poglądy na współoddziaływanie praktyk duchowych i kulturowych były wyrażane także przez przedstawicieli sfery kulturowej i to nie tylko w odległych epokach, kiedy kultura była podporządkowana religii, lecz także i we współczesności. Jako przykład z przyjemnością odwołam się do Jerzego Grotowskiego, wielkiego nowatora teatralnego XX wieku. Grotowski był bardzo bliski myśli Artauda, kontynuował jego idee, nadzwyczaj go cenił - co nie przeszkadzało mu w tym, by ze swej strony nie przyjmować absolutnego charakteru sztuki i teatru, do czego przekonywał Artaud. Przytoczę niedługi cytat z Grotowskiego: „Artaud marzył o tym, że nowe mity będą powstawać $\mathrm{w}$ teatrze, jednakże to piękne marzenie pojawiło się jako rezultat nieścisłości. Mit formułuje zasadę bądź ramy działalności pokoleń ludzkich... dlatego stworzenie mitu... nie jest dziełem teatru. Szczytem jaki może osiągnąć teatr jest możliwość krystalizacji mitu”. Bez problemu dostrzeżemy, że mówi się tu, tylko w innym języku, o relacjach praktyk duchowych i kulturowych, a relacja ta jest przedstawiona dokładnie w taki sposób w jaki przedstawiliśmy ją powyżej. W języku Grotowskiego "mit” jest tym, czym u nas jest praktyka duchowa, a to, co on formułuje jest „podłożem bądź ramami działalności pokoleń”, czyli, rzecz jasna, konstytucja człowieka. Teatr natomiast, według Grotowskiego, nie może nieść tej konstytutywnej funkcji, lecz może „wspomagać krystalizacje mitu”, czyli w naszym języku - może on pełnić rolę praktyki podtrzymującej, poprzez artykułowanie i wzbogacanie założonego wcześniej rdzenia konstytucji. Dlatego bez żadnej wątpliwości, w kwestii relacji praktyk duchowych i kulturowych jesteśmy jednomyślni z Grotowskim, dzięki czemu jawi się on jako nasz poplecznik.

Powyższe wywody opisują interesującą nas relację w sposób niepełny. Doświadczenie podpowiada nam, że praktyki kulturowe wcale nie muszą odgrywać roli praktyk podtrzymujących praktykę duchową, tak hezychastyczną, jak i każdą inną; mogą one nie mieć z nią żadnej więzi, mogą być $\mathrm{z}$ nią w konflikcie, mogą być wobec niej wrogie itd. To jednak nie przeczy naszym koncepcjom. Nasze wywody wskazują na to, że praktyka kulturowa nie jest kon- stytutywną, pełni ona jedynie rolę praktyki podtrzymującej dla pewnej praktyki konstytutywnej. Jednocześnie praktyka konstytutywna wcale nie musi być praktyką duchową. $\mathrm{W}$ pojmowaniu antropologii synergicznej człowiek jest na wskroś pluralistyczny: istnieje cały zespół formacji antropologicznych, z których każda odpowiada konkretnemu paradygmatowi konstytucji człowieka jako takiego. Praktyka hezychastyczna odpowiada formacji Człowieka Ontologicznego, która konstytuuje się w aktualizacji relacji człowieka z Bogiem, w kwintesencjalnym chrześcijańskim doświadczeniu synergii i przebóstwienia. Wraz z nią istnieją jeszcze inne formacje, które konstytuują się w aktualizacji relacji z nieświadomością („Człowiek Ontyczny”) oraz $\mathrm{w}$ wystąpieniach $\mathrm{w}$ antropologiczną rzeczywistość wirtualną („Człowiek Wirtualny”); można wyróżnić jeszcze inne formacje. $\mathrm{W}$ różnych okresach historycznych istnieje pewna najbardziej rozpowszechniona formacja, tzw. formacja dominująca, a wraz $\mathrm{z}$ biegiem historii te formacje dominujące zmieniają się. Tego typu zmiana wchodzi w skład wymiaru antropologicznego procesu historycznego. W Nowożytności i Oświeceniu długi okres dominacji Człowieka Ontologicznego, odpowiadającego prymatowi religii w społeczeństwie, powoli zbliża się do swego końca. $\mathrm{W}$ minionym stuleciu formacją dominującą był Człowiek Ontyczny, a następnie, już w naszych czasach, Człowiek Wirtualny. W świetle tej ewolucji antropologicznej zrozumiałe jest, że praktyki kultury zachodniej, włączając w nie także świat wschodniochrześcijański, już dawno pełnią rolę praktyk podtrzymujących, w szczególności, nie dla praktyki duchowej, lecz $\mathrm{w}$ stosunku do innych praktyk konstytutywnych. (Na przykład, nie raz już wspominana kultura modernizmu mocno związana jest z konstytucją, powodowaną przez nieświadomość.) Koniecznie zauważyć musimy i to, że, nie posiadając możliwości formowania konstytucji człowieka, praktyki kulturowe władają jednocześnie wolnością i autonomią: świadomość kulturowa może rozwijać praktyki podtrzymujące także dla takiego paradygmatu konstytucji, który w danym okresie nie jest dominującym. Na tym właśnie polega jeden ze sposobów wyrażania wolności artysty. Tego rodzaju różnice, konflikt praktyk kulturowych i trendów z panującymi formacjami sprowadzają te praktyki do nurtu przeciwstawnego, protestu, dzięki czemu nieraz odgrywają one ważną rolę w rozwoju kulturowym i społecznym.

$\mathrm{Na}$ koniec relacje hezychazmu i kultury, praktyki duchowej i praktyki kulturowej zostały opisane bardziej wszechstronnie. Okazuje się jednak, że nie są one bardzo proste. Praktyki kulturowe mogą pełnić rolę praktyk podtrzymujących nie tylko dla konstytucji Człowieka Ontologicznego, lecz, mówiąc ogólnie, dla jakiegokolwiek typu konstytucji. W historii spotykaliśmy się z ich współoddziaływaniem $\mathrm{z}$ różnymi typami, a we wszystkich tych przedsięwzięciach ich relacje $z$ hezychazmem mogą przybrać różnoraki charakter - może dojść między nimi do współpracy, ale także do jawnej wrogości. Wynika z tego, że przed nami znajduje się istotne zadanie na przyszłość: w ślad za opisem relacji hezychazmu i kultury „w zasadzie”, na poziomie konceptualnym, powinniśmy opisać je „w czasie re- 
alnym", prześledziwszy to, w jaki sposób zmieniały się one w historii. Jedynie bardzo ogólnie teraz to zasygnalizujemy. $(\ldots)$

\section{5}

„Rozwody i powroty”: taką formułą o. Jerzy Florowski określił specyficzny charakter rosyjskiego rozwoju duchowo-kulturowego. Rewolucja bolszewicka i ustrój sowiecki były z pewnością przyczyną jednego z najradykalniejszych rozwodów. Duchowa i kulturowa historia Rosji wstąpiły w przewlekły i ciężki okres degradacji, która zmieniając fazy i formy trwa po dziś dzień. Zarówno hezychazm rosyjski jak i kultura rosyjska musiały przetrwać lata wyrugowania i sprzeciwu, funkcjonowania katakumbowego. Jednakże życie ich, mimo że w rozproszeniu, trwało nadal, a w ich relacjach osiągnięte zostały także sukcesy. Zauważyliśmy już, że hezychazm rosyjski charakteryzowal brak zainteresowania wymiarem teologicznym praktyki hezychastycznej, nieobecność przyswojenia - nie mówiąc nic o jakimkolwiek rozwoju - teologicznego zrozumienia doświadczenia hezychastycznego w palamasowej teologii energii boskich. W okresie emigracyjnym cecha ta została przezwyciężona. Jak już na początku powiedzieliśmy, teologowie emigracji rosyjskiej zostali prekursorami neopalamizmu, a w kontekście naszego tematu „Hezychazm i kultura” ważne jest to, że w kręgu najwybitniejszych pisarzy współczesnej teologii energii znajdują się także zamieszkujący Św. Górę Atos mnisi-hezychaści - abp. Bazyli (Krywoszein) i ihumen Sofroniusz (Sacharow).

Ostatecznie, z naszego opisu wyłania się ogólny obraz danej tematyki. Mogliśmy się przekonać co do tego, że stosunek hezychazmu wobec kultury zawiera w sobie dwa różne nurty. Przede wszystkim stosunek wobec kultury świeckiej oraz niebezpośrednio wobec kultury tego społeczeństwa, w którym istnieje - nawet jeśli się od niego odłącza - tradycja ascetyczna. Ten właśnie nurt staraliśmy się prześledzić w sposób szczególny w naszej analizie; jednak poza tym dość oczywistym nurtem istnieje jeszcze inny. Fenomen hezychazmu, praktyka hezychastyczna i tradycja niosą w sobie konkretne własne aspekty kulturowe, możliwości kulturowe. Praktyka hezychastyczna zawiera w sobie refleksję, a cały szereg elementów jej metody - takich jak tłumaczenie doświadczenia - składa się na praktyki intelektualne i kulturowe. Pod pewnym względem także teologia jest pewną częścią praktyki hezychastycznej, ponieważ w prawosławiu na szeroką skalę przyjęty został wspomniany już wyżej sposób traktowania teologii jako bezpośredniego opisu osobistego doświadczenia wspólnoty z Bogiem, która osiągana jest na wyższych stopniach drabiny hezychastycznej. W związku z tym mamy podstawy, by twierdzić, że istnieje zjawisko, które można nazwać immanentna kultura hezychazmu i które można określić jako aktualizację aspektów i możliwości kulturowych, znajdujących się w praktyce i tradycji hezychastycznej. (Zauważmy i to, że analogiczne zjawisko można przeciwstawić wszelkiej praktyce duchowej.) Pojęcie immanentnej kultury hezychazmu jest bliskie wprowadzonemu powyżej pojęciu praktyki podtrzymującej i pozytywnie je dopełnia: zorientowana na hezychazm i zbliżająca się do niego praktyka podtrzymująca przynależy mimo wszystko do kultury zsekularyzowanej, świeckiej.

Jako przykład wskażemy pewne fenomeny i epizody, w których wyrażenie znajduje immanentna kultura hezychazmu. Po pierwsze, mamy na myśli tworzoną przez hezychazm literaturę, która stanowi znaczący zbiór tekstów i nosi nazwę „Filokalii”, która nie jest bynajmniej zbiorem zakończonym. Do tego zbioru można zaliczyć również syntezę ascetyki i patrystyki: tworząc wraz z patrystyką syntezę, ascetyka odnajduje w sobie elementy wspólne bądź spokrewnione z teologią patrystyczną. Podkreślaliśmy już wcześniej, że takim ważnym elementem jest dyskurs przebóstwienia; można także uznać, że teologia ascetyczna św. Maksyma Wyznawcy w całości przynależy immanentnej kulturze hezychazmu. Do niej niewątpliwie przynależy palamasowa synteza myśli prawosławnej: w teologii Palamasa i w całym bizantyjskim renesansie hezychastycznym immanentna kultura hezychazmu była w stanie wyrazić się w bardzo klarowny sposób (co odróżnia ją, niestety, od rosyjskiego renesansu hezychastycznego, który był mniej różnorodny). Następnie przy rozpowszechnianiu hezychazmu na Bałkany i Ruś pojawia się bardzo osobliwe zjawisko szkoły ascetyczno-filologicznej: wówczas gdy środowisko mnichów-hezychastów zajmuje się ciężką pracą filologiczną, analizuje teksty, tłumaczy i publikuje rękopisy hezychastyczne. Były trzy takie główne szkoły w rożnych państwach: Tyrnowska szkoła literacka w XIV wieku w Bułgarii, szkoła św. Paisjusza Wieliczkowskiego w Mołdawii w XVIII wieku oraz rosyjska szkoła w Pustelni Optyńskiej w XIX wieku. Działalność takich szkół jest wyraźnym przykładem immanentnej kultury hezychastycznej. Wiadomo, że oni są blisko związani z nurtem „kultury monasterskiej”: można powiedzieć, że szkoły ascetyczno-filologiczne stanowią specyficzną hezychastyczną formę kultury monasterskiej, odróżniającej się tym, że zarówno zadania, jak i cała działalność tych szkół podporządkowane są praktyce hezychastycznej i są z nią zintegrowane. Kultura monasterska również, co oczywiste, przynależy immanentnej kulturze hezychazmu (a na Zachodzie immanentnej kulturze monastycyzmu katolickiego).

Owoce pracy hezychastycznych szkół filologicznych były bardzo ważne. Wystarczy przypomnieć sobie, że w szkole św. Paisjusza Wieliczkowskiego stworzono słowiańską wersję „Filokalii”, której pojawienie się było przyczyną duchowego odrodzenia $\mathrm{w}$ całym świecie prawosławnym - ruchu, który otrzymał nazwę „filokalicznego odrodzenia" i pod pewnym względem nie ustał do dziś. Praktyki kulturowe, jakie były rozwijane w nurcie odrodzenia filokalicznego, pod wieloma względami można również odnieść do immanentnej kultury hezychazmu, a w ich całokształcie dostrzegamy zbliżenie się i współpracę, swego rodzaju konwergencję praktyk kultury świeckiej i immanentnej kultury hezychazmu. Tego rodzaju konwergencja bądź, w szerszym sensie, synergia, jest jeszcze bardziej charakterystyczna dla współczesnej teologii neopalamasowej: zgodnie z tym, co już mówiliśmy, w jej nurcie myśl 
świeckich uczonych i mnichów-hezychastów rozwijana jest w nierozerwanej jedności. Taką jedność można zaobserwować w pracy kulturowej, jaka dokonuje się współcześnie na Górze Atos.

W tym zjawisku konwergencja relacji hezychazmu i kultury, tradycji duchowej i tradycji kulturowej, przybiera formę współpracy i dialogu. Jest to charakterystyczne dla współczesności: powracając do początku możemy przypomnieć sobie o przechodzeniu współczesnego świata w paradygmat postsekularny, w fazę postsekularnego dialogu.
Formułując nową konfigurację relacji między świadomością świecką i religijną, współczesna sytuacja niesie ze sobą także nowe możliwości zbliżenia miedzy kulturą świecką i immanentną kulturą hezychazmu. Dlatego można mieć nadzieję, że w takim zbliżeniu, które prowadzi do twórczej synergii dwóch różnych typów kultury odsłania się perspektywa owocnego istnienia tradycji duchowej we współczesnym społeczeństwie.

przettumaczył ks. Łukasz Leonkiewicz 